監化加里として分離せり・

本研究をなすに當り試料の探集站に普通成分の分析は西野利雄及田中正吉兩 氏の助力を得たことを兩氏に深謝す。

引用文献

1) Dutcher and Collotzi; J. Am. 36, 547-550 (1918).

2）三宅啑. 柇幌農林學會報 18, 19, (1921).

3) $" \quad$ 11, 24, (1921).

4) Fred and Peterson; J. Ind. \& Eng. Chem. 18 , 211-213, (1921).

5) Mouroe; " $\quad$ 18, 133-135, (1921).

6) Kerr and Stewart; American industries, February. 16-51, (1910); Burtt-Davy; Maize, 693, (1914).

7) Perold; Agricultural Journal of the Union of South Africa, 1911, May.

8) Wood, Remington and Sadtler; U. S. Pharmacopoeia, I: Burtt-Davy ; Maize, 802. $\left(1911^{d}\right)$.

9) Radimaker and Fischer; Am. J. of Pharm. 369, (1886).

10) Burtt-Davy; Maize, 802., (1914).

11) Lippman; Die Chemie der Zuckerarten, I, 1904, p. 535: Ber. 17 , 579; I8, $1660^{\circ} ; 20,827$; $1,987$.

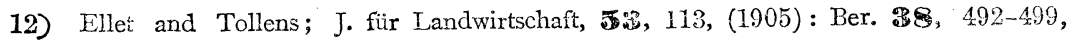
(1906).

13) Oshima and Kondo; Journal of the Tokyo chemical Society, 8:9, No. 3, 185-108, (1918).

14) Lippmann; Die Chemie der ${ }_{\llcorner}$Zuckerarten, I, 720, (1904).

15) Abderhalden; Biochemisches Handlexikon, II, 507, (1911).

16) Lippmann; Die Chemie der Zuckerarten, I, 140, (1904).

\title{
〔學 事 雬 颕〕
}

\section{I. 無機化學 肖機化學}

オキシム類の接觸澴元 G. Vavon \& Krajcinovic : Bull. Soc. chim. France (4), 43，231-37(1.928) オキシムの接觸還元に依りては通常對應する第一級, 第二級或

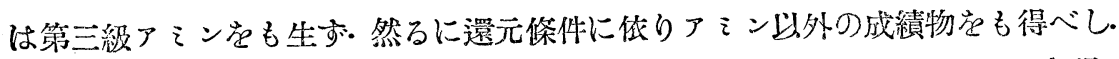

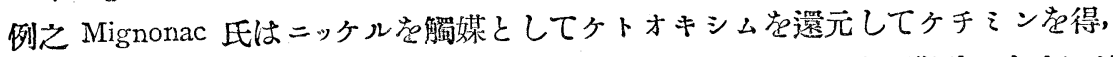
又著者等の一人 V 氏は虂に Berton 氏と協力して含水酒精溶液中签酸の存在に於 
てチクロへキサノンオキシム农還元して $\beta$ てクロへキシルヒドロキシラそンを 得たり・本反應は環狀ケトンオキシムには一般なるものの如し. 著者等は今他の ケトンオキシム及アルドキシムに就て接觸還元觉行ひ次の結果に到噠したり・節 脂肪族ケトン(ヂプロピルケトン,メチルイソブチルケトン)オキシムは還元に依り 對應する第一級 $\beta$-ヒドロキシルアネンを生じ区應アルドキシム(イソワレルアル デヒド及エナントール）よりは次式の如く第二級ヒドロキシラミンとアンモニア

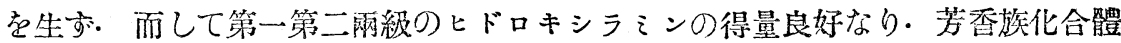
$2 \mathrm{RCH}=\mathrm{N} \cdot \mathrm{OH}+\mathrm{EH}=\left(\mathrm{R} \cdot \mathrm{CH}_{2}\right)_{2} \mathrm{~N} \cdot \mathrm{OH}+\mathrm{NH}_{3}+\mathrm{H}_{2} \mathrm{O}$

に於てはアルドキシム(ベンッアルデヒド及ピぺロナール)より第二級ヒドロキシ ラミンを生亦る事は同樣なるも得量は中㡾なり・而してアセトフェノンオキシム

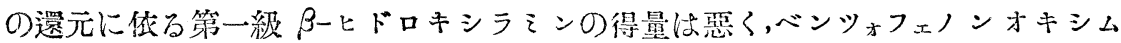
にめりては成績物は第一級アミンのみにしてヒドロキシラミンは得られず，其理

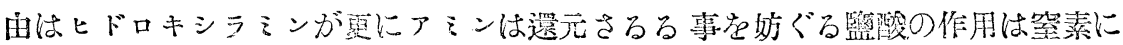

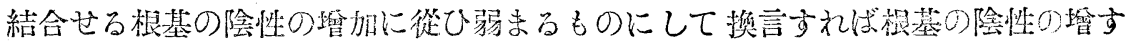
と共に生成ヒドロキシラそンの雷基性弱くなるに基く・而して及多トンオキシム とアルドキシムとの結果の差珙は次の如く之を說明し得. Bamberger, Tattermann

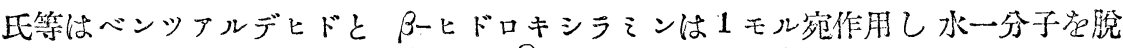

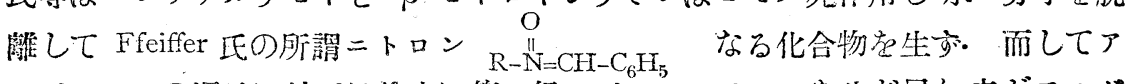
ルドキシょの還元に於ては途中に第一級ヒドロキシラ々ンを生じ居りえがァルド

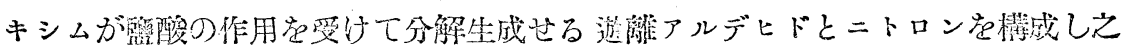

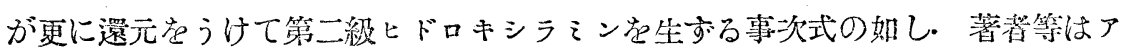

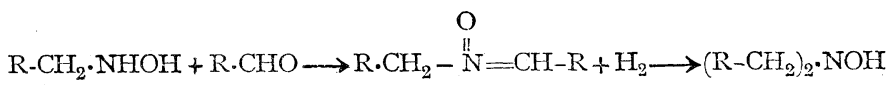

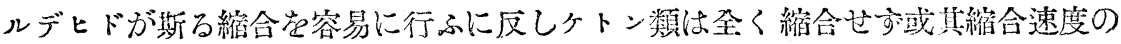

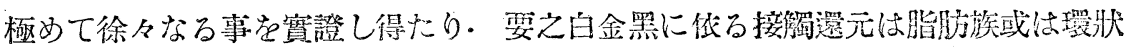
ケトンオキシンムより第一級ヒドロキシラミンを製する法及び能肪族アルドキシ ムより第二級ヒドロキシラミン製する法として卓越せるものなりとす・(管瀑)

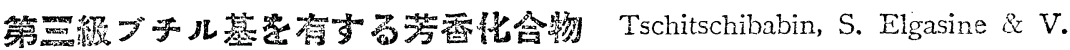

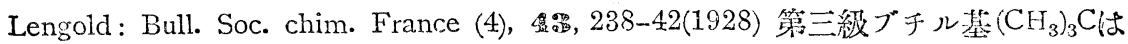

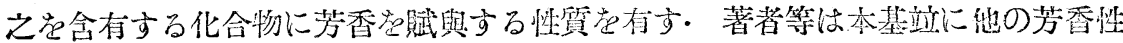
殘基党有す万化合物の合成足企てたり・先づ原料として tert.ブチルブロームべ ンツォールを取る・本品は tert.ブチルベンツォールに接触劑の存在に於てブロ一

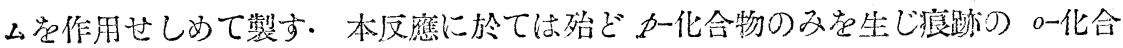
物を混在するに不過。而に之にマグネシウム怒作用せしむる時はグリニャール試

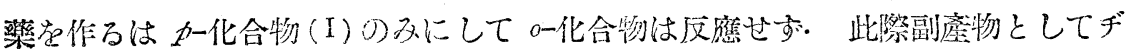


ーp-tertーブチルヂフェニル(II)危生ず，（I）に正舢酸エステルを作用せしむる時は途

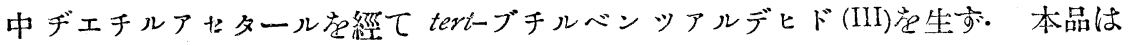
沸默 238-40 $160^{\circ}$, と共に强き芳香觉有市. (III) 觉酸化する時は先づ p-tert. ブチル安息香酸 (V) を生じ, 夏に强く酸化する時はテレフタール酸觉生ず（I）をエチレンクロール七 ドリンと作用せしむる封は p-tert. ブチルフェニルェチルアルコホル (VI), 沸唯 $1.5 \mathrm{~mm}$ にて 141-143，を生ず, 本品は强き特異の芳香觉有しフェニルェチルアル コホルに類似せるも同時に香は葶香に類す。

(管澤)

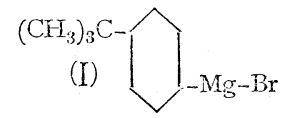

(IIII)
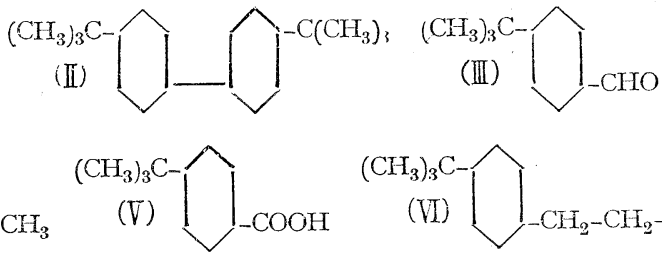

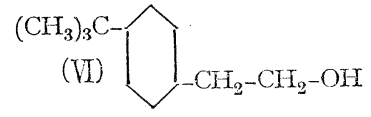

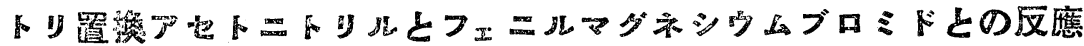

R. Lucas \& F. S. Legagneur: Bull. Soc. chim. France 4, 1893, 321-29 (1928) 著者 等は的究上(I)，(II) 及(III)(Rはアルキル，Ar はアリル)式の如きケトンを必要とした

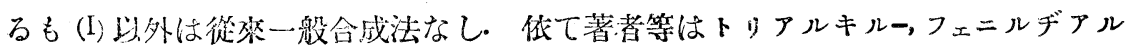
キルー及びヂフェニルアルキルアセトニトリルにタェニルマダ秝ムブロにドを 作用せしð良好なる得量觉上て所求の置換ケトン類を得たり・而して一般に中間

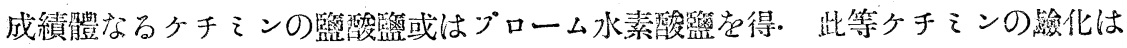

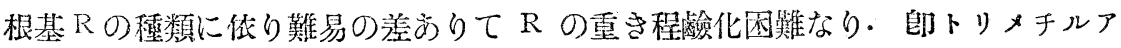

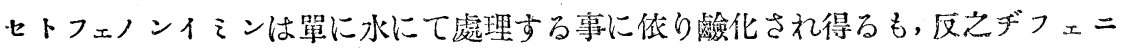

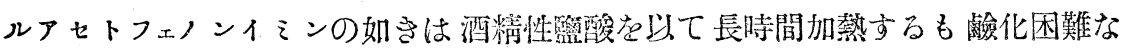
り・而して此等安定なるケチてンに對しては醋酸ソーダの醋酸溶液が良好なる結

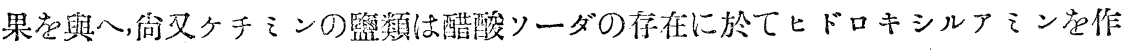
用せしむる時は容易に㦠應するケトンのオキシムを生ずる事学發見したり・ケト ンの得量はニトリルの分子量小なる程良努なり・攵ヂフェニルベンチルアセトニ トリルに對してはフェニルマグネシウムブロにドは作用せざるも，反之心゙ンチルマ グネシウムクロリドはヂフェニルベンチルー或はトリフェニルアセトニトリルと作

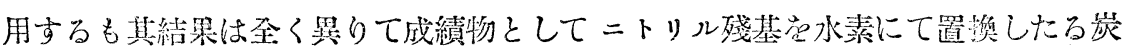
化水素, メタルアニド,デベンチル等を生ず, 此結照は次式に依りて院明し得.

(菅濢)

$$
(\mathrm{R})_{3} \cdot \mathrm{C} \equiv \mathrm{N}+2 \mathrm{C}_{6} \mathrm{H}_{5} \cdot \mathrm{CH}_{2} \cdot \mathrm{Mg} \cdot \mathrm{Cl} \longrightarrow(\mathrm{R}) 3=\mathrm{C}-\mathrm{Mg}-\mathrm{Cl}+\left(\mathrm{C}_{6} \mathrm{H}_{5} \cdot \mathrm{CH}_{2}\right)_{2}+\mathrm{Mg} \cdot \mathrm{Cl} \cdot \mathrm{CN}
$$


<smiles>[R]CC([R])(C)C(=O)OCC</smiles>

(I)<smiles>[R]C([Y17])([Y])C(=O)OCC</smiles>

(II)
$\mathrm{R} \backslash$
$\mathrm{Ar}-\mathrm{C}-\mathrm{CO}-\mathrm{C}_{6} \mathrm{H}_{5}$
$\mathrm{Ar}^{\prime} \quad$ (III)

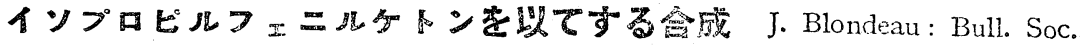

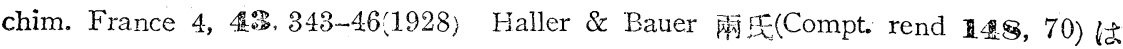
$\mathrm{C}_{6} \mathrm{H}_{5}-\mathrm{CO}-\mathrm{C}\left(\mathrm{R}, \mathrm{R}^{\prime}, \mathrm{R}^{\prime \prime}\right)$ なるケトンの一般会成法に成功したり・而して $\mathrm{H}$ 民は面に

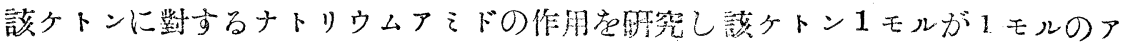

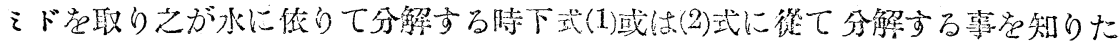

$$
\begin{aligned}
& \begin{array}{cc}
\mathrm{C}_{6} \mathrm{H}_{5} \cdot \mathrm{CO} \cdot \mathrm{C}\left(\mathrm{R}, \mathrm{R}^{\prime}, \mathrm{R}^{\prime \prime}\right)+\mathrm{NaNH}_{2}=\mathrm{C}_{6} \mathrm{H}_{5}-\stackrel{\mathrm{ONa}}{\mathrm{C}}-\mathrm{C}\left(\mathrm{R}, \mathrm{R}^{\prime}, \mathrm{R}^{\prime \prime}\right) \\
1 \\
\text { iv } \mathrm{H}_{2}
\end{array} \\
& \mathrm{C}_{6} \mathrm{H}_{5} \cdot \mathrm{CO} \cdot \mathrm{C}\left(\mathrm{R}, \mathrm{R}^{\prime}, \mathrm{R}^{\prime \prime}\right)+\mathrm{H}_{2} \mathrm{O} \nearrow_{-\mathrm{NH}_{2} \cdot \mathrm{CO} \cdot \mathrm{C}\left(\mathrm{R}, \mathrm{R}^{\prime}, \mathrm{R}^{\prime \prime}\right)+\mathrm{C}_{6} \mathrm{H}_{6}+\mathrm{NaOH} \cdots \cdots \cdots \cdot 2 .}^{\mathrm{C}_{6} \mathrm{H}_{5} \cdot \mathrm{CO} \cdot \mathrm{NH}_{2}+\mathrm{CH}\left(\mathrm{R}, \mathrm{R}, \mathrm{R}^{\prime \prime}\right)+\mathrm{NaOH} \cdots \cdots \cdots \cdot 1 .}
\end{aligned}
$$

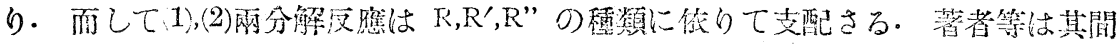

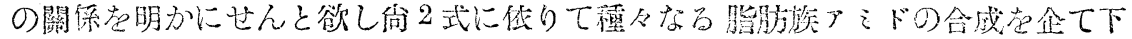
記り如き諸物質觉得たり・フェニルー1,ーヂメチルー2,2一へキサノンー1. $\mathrm{C}_{6} \mathrm{H}_{5} \cdot \mathrm{CO} \cdot \mathrm{C}$ $\left(\mathrm{CH}_{3}\right)_{2} \cdot \mathrm{C}_{4} \mathrm{H}_{9}$. イソプロピルフェニルケトン,ナトリウムア

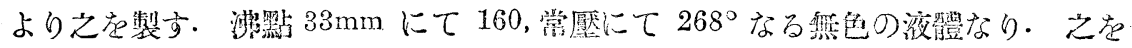

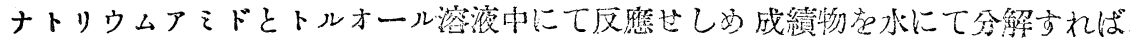

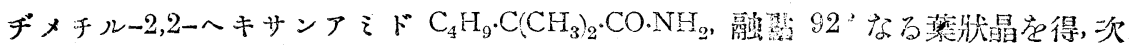

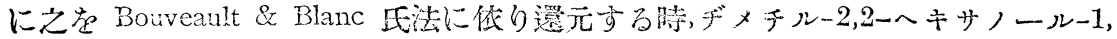

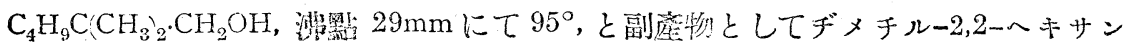

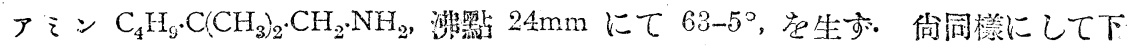
記物質策得たり.

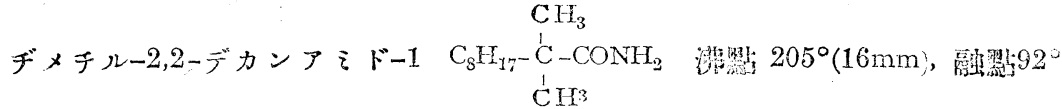

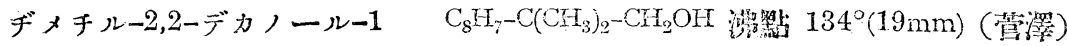

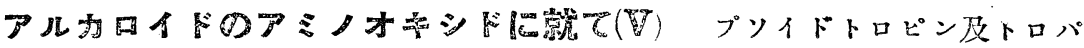
コカインの N-オキシド Max \& M.Polonovski: Bull. Soc. chim. France (4), 48,

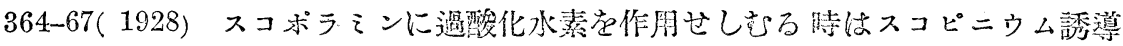

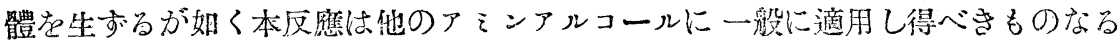
やを檢せんとしスコボランに近きアトロピンに同愫に過撆化水素厹作用せしめ たるに第四級唀䆃體の生成を認め得ざりき，思ふにアルコール性水酸基とアぇ， オキシドのオキシヒドリル間のエーテル生成は水酸基の立體的位置に俄り支配さ るるものの如く,依て次にプソイドトロピン及其心゙ンツォイル誘導艘郎トロパコナ 
インに訨り上記の目的を澾せんとしたり·依てトロパコカイン及プソイドトロピン のN-オキシド筡したるが目的たるトロピニウム化合物の倩成定認め得ざりき・ト ロパコカインNーオキシト(I：トロパコカイン, 融點 $49^{\circ}$, 觉アセトン溶液に於て過酸

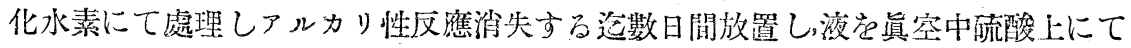

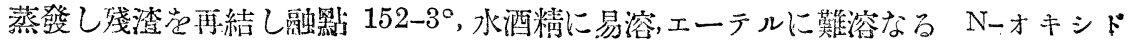

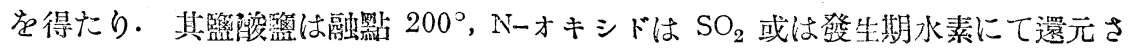
れてトロバコカイン学逆生す.プソイドトロピンの N-オキシド(II)：トロパコカ

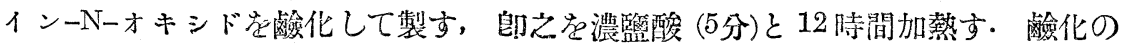
途中數次加熱を中止し生成安息否酸苞エーテルにて抽出し逐に安息否酸つ生成せ

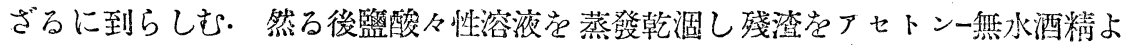

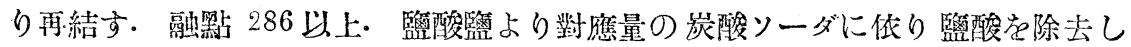
蒸發乾涸殘渣を绶水酒精にて抽出し食監と分つ㭙プソイドトロピンーNーオキシド は融點 $229^{\prime}$ の無色葉狀晶として得らる・ ピクラートの分解默 $257^{\circ}, \mathrm{SO}_{2}$ により てプソイドトロピン,渙點 $108^{\circ}$, 军生す。・ロパコカインーNーオキシドよりノルプ

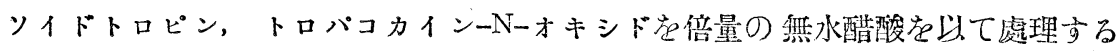
特 N-アセチルOーベンツォイルノルプソイドトロピル (III) 觉生交. 之定完酒精

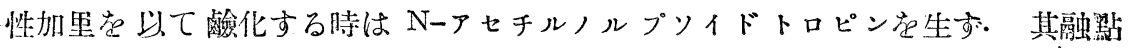

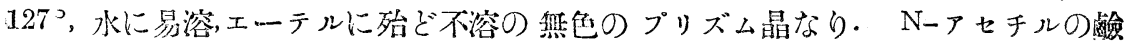

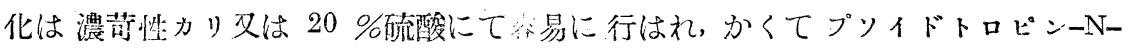
オキシドに留水醋酸を作用せしめて得らるる，N，Oーヂァセチルノルプソイドト ロピンの襝化によりて得たると同じノルプンイドトロピン茛得.

(癔濢)

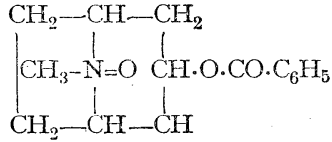

(I)

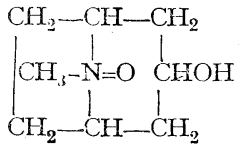

(II)<smiles>CC(=O)NC1CC2CCCC(C1)C2OC(=O)c1ccccc1</smiles>

(III)

ケトン装頁の合成淁 D. Ivanoff: Bull. Soc. chim. France (4), 43，441-47

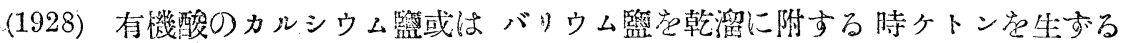
は古くより知らる・著者は上記䉒類の代りにR.COOMg.Xなる有機酸の混合マグ ホシウム籃を加熱して同㨾にケトンを製し得たり・其反應次式の如し.

$$
2 \mathrm{RCO}_{2} \mathrm{Mg} \cdot \mathrm{X}=\mathrm{R} \cdot \mathrm{CO} \cdot \mathrm{R}+\mathrm{Mg} \mathrm{X}_{2}+\mathrm{MgCO}_{3} \longrightarrow \mathrm{MgO}+\mathrm{CO}_{2}
$$

而して炭酸マグネシウムが分解して生ずる孷酸ガスはケトンの生成を促進せしも。

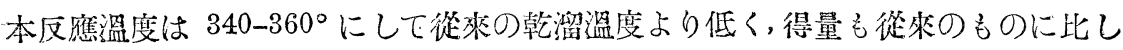

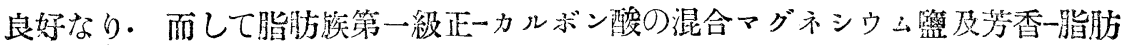

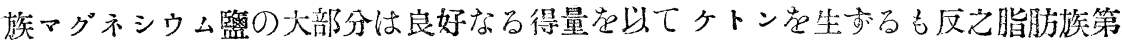


二級, 芳香㵀及水素化芳㿢族化合體に在りてはケトンの得量惡く，エチレン系岸化

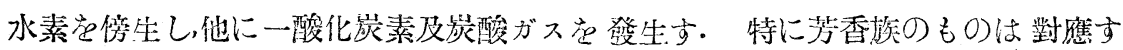
る炭化水素の著量を生恋，著者は有㙨酸マグネシウム局樣に乾溜したるに上記

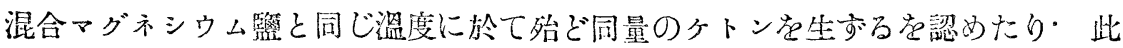

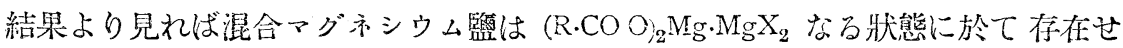

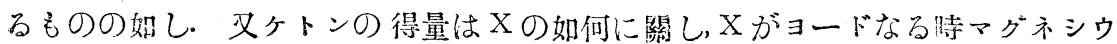

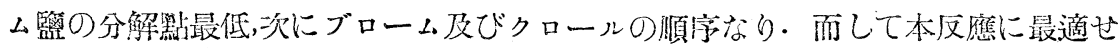
るものはっロール及びブローム化合物にして R.COOMg.Cl(Br)は一般に結晶性粉 末にして溶剂エーテルの除去容易なり．反之第二級のカルボン酸のマグネシウム 籃に於て $\mathrm{X}=\mathrm{Br}$ 或は Jなる時 R.COO.MgX は一般に油狀にしてェーテルの除去

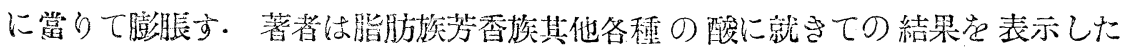
り.

(菅澤)

ナフタ明ン莯のアミノアルコホル類の含虚 E. Fourneau \& Tréfouel; Bull. Soc. chim. France (4), 43，454-58.1923） ヒニンは其分子中にヒノリン及ヒ ヌクリヂン核を有するアえノアルコホルなり・著者等はヒニンの如く分子量大な

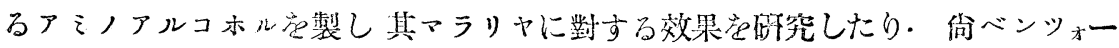
ル列に屬するものにてヒニンと同樣にメトキシ基及ピペリヂン核を有するものを 製し此等製品に就きて其生理作用在檢し其中一化合物が明かに有效なるを認めた

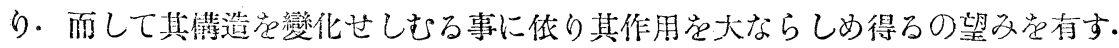
1. ナフチルプロパノールの誘導體. 先つ原料としてのナフチルプロパ，ールク ロールヒドリンは $а$ ロナフルマグネシウムブロえドとエピクロールヒドリンよ

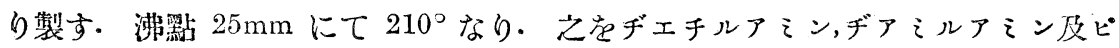
ペリデンと作用せしむ. 或は本っロールヒドリン范アルカリにて處理してェチレ

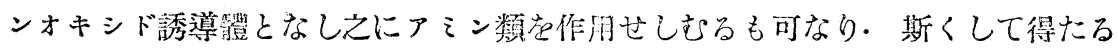
ヂメチルアiノナフチルプロバノール $\mathrm{C}_{10} \mathrm{H}_{7} \cdot \mathrm{CH}_{2} \cdot \mathrm{CHOH} \cdot \mathrm{CH}_{2} \cdot \mathrm{N}\left(\mathrm{CH}_{3}\right)_{2}$ は沸點 21.6-

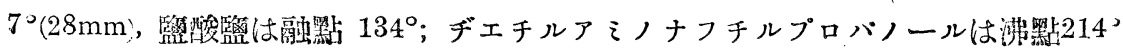

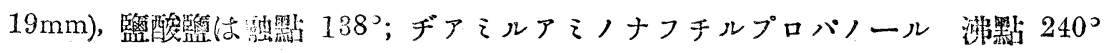

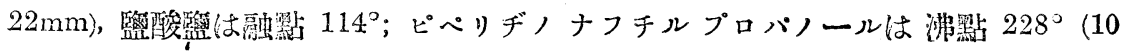

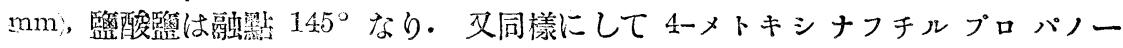

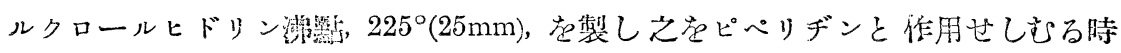

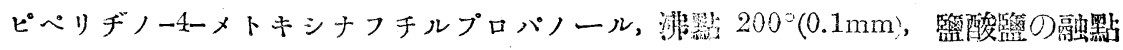

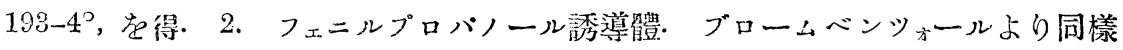

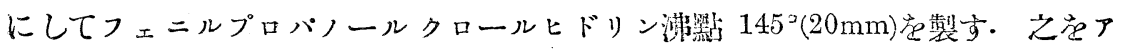

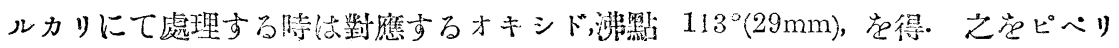

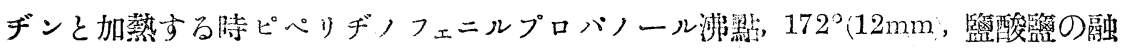


點 178-9², 爷得. 同樣にして得らるるピペリヂノーかーメトオキシフェニルブロパ

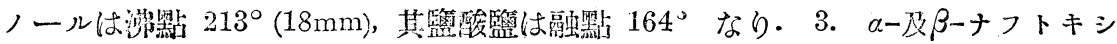
プロパノール誘導體. にて緬合せしめて

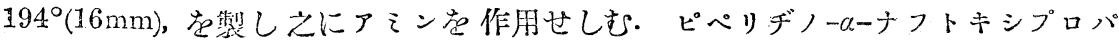

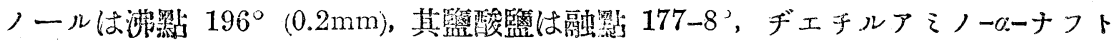

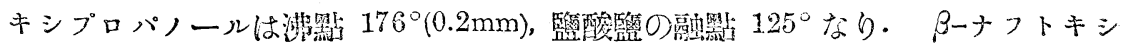

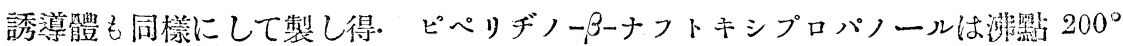

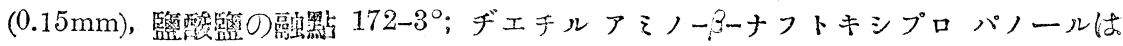

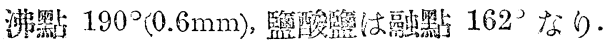

（管澤）

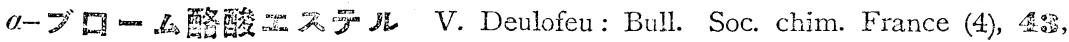

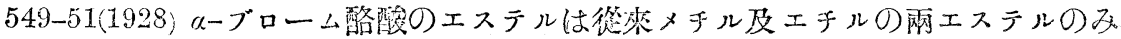

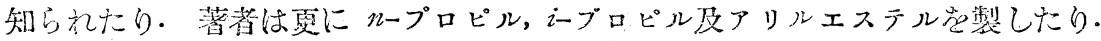

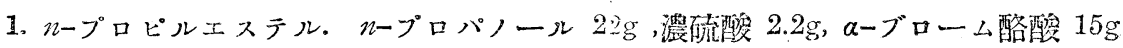

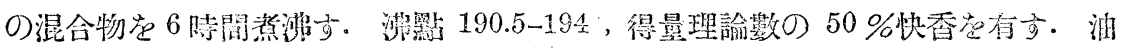

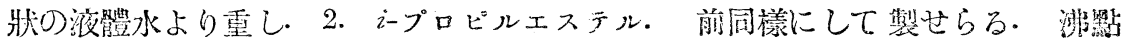

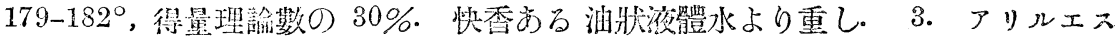

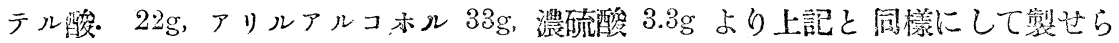

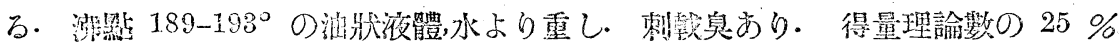
なり・

(管滰)

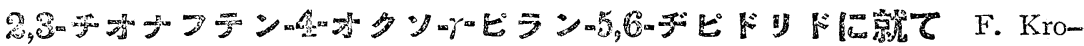

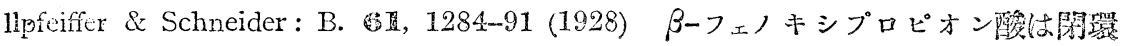

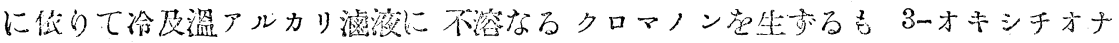

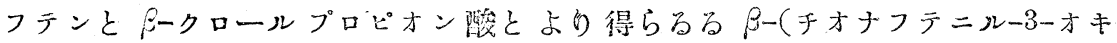

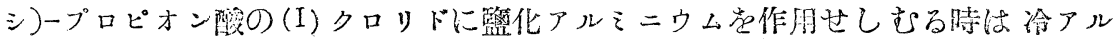

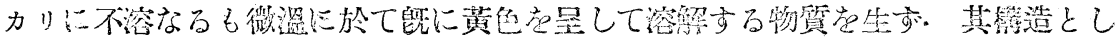

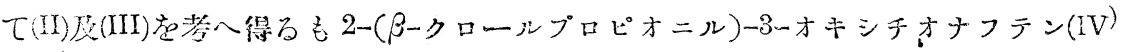

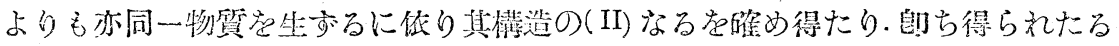

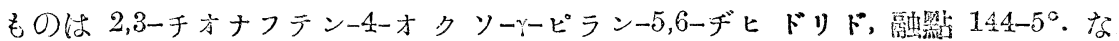
り. 3ーオキシチオナフテンメチルエーテルにアセチルクロリド及゙゙ンツォイルク ロリドを作用せしさる時は Smiles 氏がチオサリチール酸にアセチルアセトン及 ベンツォイルァセトン毞作用せしめて得たるものと同一なる2-アチルー3ーオキシ チオナフテンを生实. 而して酸クロツドとして ドを作用せしもる時は 2-( 
な生す。 之を亞鉛と醋酸を连て息元する時は 2-プロピオニルー3ーオキショオナン

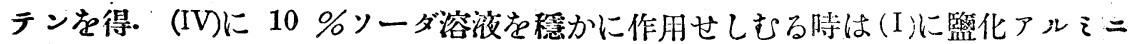
ウムを作用せしめたると同一物質を得. 又( IV)の微温アルカリ溶液を酸性となす 時は(II)のアルカリ溶液を酸性となしたる時と同一物質を生じ過クロール鐵に依り て其酒精溶液は 2-アチルー3-オキシチオナフテンに特有なるオリーブ綠色を呈す。 其他分析, フェニルイソチアナートに對する反應等より之が $2-\beta$ ○キシプロピオ ニル)ー3ーオキシチオナフテン (V) なる事確賽なり、即クロマノン環はアルカリに 對し安定なるも對應するチオナフテン㮇導體なる(II)はアルカリに依り容易に開 環するを知り得. 又(I)はクロマノンと異りベンッァル誘導體を作らず 及ブロ一 ム誘導體の生成も困難なり.されど濃厚ブロームの過剩觉作用せしもる㭙デメチ

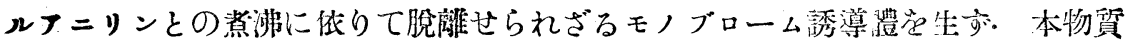
はナルカリに谓色觉呈して溶解し其より酸にして沈澱せしめたるものは同樣ブロ 一ムを含有するも既に原物質とは異り，分析及過クール鐵反應に依れば(V）のブロ 一ム誘導體にして而もブロームをべンツォール核に有するが如く，物質の得量僅少 にして精查し得す,又ブローム化オキシチオナフテンより同一物質觉得んとしたる

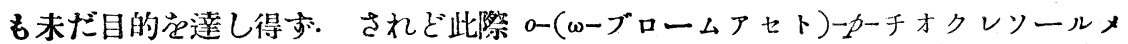
チルエーテル(VI)より签易にブロームメチルを脫離して 5ーメチルー3ーオキシーチオ ナフテン(VII)党生亦る事を知りたり・一般にチオフェンールメチルエーテルのメ

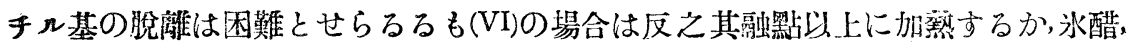
トルォール或は水蒸氣蒸溜に於てすらブロームメチルの脫陮在見る。（管摆）

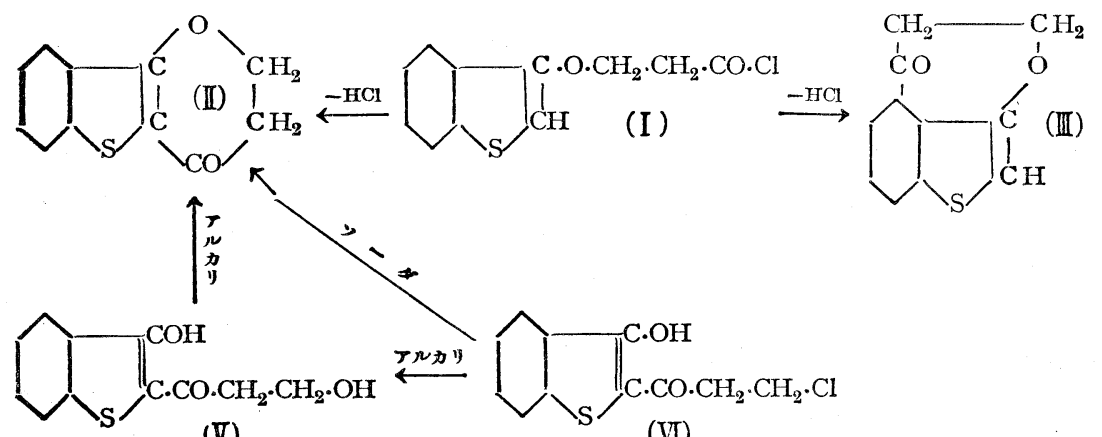

(V)

(V)<smiles>CSC1CCC(C)CC1C(=O)CBr</smiles>

コンヴォルプリノール酸及ャラピノール酸の櫮造に就て 11-ヒドロ キシペンタデカン酸及 11-ヒドロキシへキサデカン酸の合成 L. A. Davics \& R. 
Adams: J. Am. Chem. Soc. 50, 1749-55 (1928) Kromer 氏はャラピノール酸㤝 䍌し $\left.\mathrm{CH}_{3} \mathrm{CH}_{2} \mathrm{CH}, \mathrm{CH}_{3}\right) \cdot \mathrm{CHOH} \cdot\left(\mathrm{CH}_{2}\right)_{10} \cdot \mathrm{CO}_{2} \mathrm{H}$ 式を與へ Taverne \& Höhnel 氏等はコ ンヴォルブリノール 酸に 對し $\mathrm{CH}_{3} \cdot \mathrm{CH}_{2} \cdot \mathrm{CH} \cdot \mathrm{CH}_{3} \cdot \mathrm{CHOH} \cdot\left(\mathrm{CH}_{2}\right)_{9} \cdot \mathrm{CO}_{2} \mathrm{H}$ 式を舆へたる も之等は何れも誤りにして朝比奈教授の研究に依れば 屍酸共に直鎮化合物にして ヤラピノール酸は (I) 式即ち 11ーヒドロキシへキサデカン酸にしてコンヴォルブ リノール酸は (II) 式㓷ち 11-ヒドロキシペンタデカン酸なり・著者等は今之を合 $\mathrm{CH}_{3} \cdot\left(\mathrm{CH}_{2}\right)_{4} \cdot \mathrm{CHOH} \cdot\left(\mathrm{CH}_{2}\right)_{9} \cdot \mathrm{COOH}(\mathrm{I}) \quad \mathrm{CH}_{3} \cdot\left(\mathrm{CH}_{2}\right)_{3} \cdot \mathrm{CHOH} \cdot\left(\mathrm{CH}_{2}\right)_{9} \cdot \mathrm{COOH}$ (II) 成的に證明せんとし先ゔ原料として 11,12-ドデチェン酸メチルェステルを Noller \& Adams 兩氏[J. Am. Chem. Soc. 48, 10741926)]に依りオゾン化し之を分解して 10ーアルデヒドーデカン酸メチルを製し之を a) nーアミルマグネシウムブロにド及 b) $n$ ーブチルマグネシウムブロiドと反應せしめ所期のオキシ酸エステルを得る事

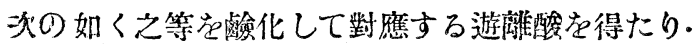

a) $\mathrm{CH}_{3} \cdot\left(\mathrm{CH}_{2}\right)_{4} \mathrm{Mg} \cdot \mathrm{Br}+\mathrm{CHO} \cdot\left(\mathrm{CH}_{2}\right)_{9} \cdot \mathrm{CO}_{2} \mathrm{CH}_{3} \longrightarrow \mathrm{CH}_{3} \cdot\left(\mathrm{CH}_{2}\right)_{4} \cdot \mathrm{CHOH}\left(\mathrm{CH}_{3}\right)_{9} \cdot \mathrm{CO}_{2} \mathrm{CH}_{3}$

b) $\mathrm{CH}_{3} \cdot\left(\mathrm{CH}_{2}\right)_{3} \cdot \mathrm{Mg} \cdot \mathrm{Br}+\mathrm{CHO} \cdot\left(\mathrm{CH}_{2}\right)_{9} \cdot \mathrm{CO}_{2} \mathrm{CH}_{3} \longrightarrow \mathrm{CH}_{3} \cdot\left(\mathrm{CH}_{2}\right)_{3} \cdot \mathrm{CHOH} \cdot\left(\mathrm{CH}_{2}\right)_{9} \cdot \mathrm{CO}_{2} \mathrm{CH}_{3}$

茲に合成しるものは勿論ラ七て型なるをりて之を直接天產活性品と比較し得ざる も同構造を有するものなりや否やは容易に闡明し得. 即ヤラピノール酸,コンヴ ォルブリノール酸を酸化して對應するケトン酸となす時は（I), (II) 兩式にして 真 ならば光學的非泀性の酸を生す可く從て之在合成兩オキン酸を酸化して製した

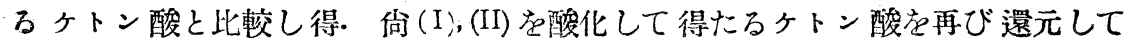
非活性の（I）及（II）となし之を合成品と其融點を比較したるに其結果次表の如 ᄂ.

\begin{tabular}{|c|c|c|c|c|}
\hline & ヤラピノール酸 & 合成 (I) & コンヴォル酸 & 合成 (II) \\
\hline 酸 & $65.5-66.5^{\circ}$ & $68-69^{\circ}$ & $51-52^{\prime}$ & $63.5-64^{\circ}$ \\
\hline メチルェステル & $46-47^{\circ}$ & $40.5-41.5^{\circ}$ & $31-32^{\circ}$ & 約 $29-82^{\circ}$ \\
\hline ケトン酸(酸化に依ろ) & $74-75^{\circ}$ & $74-75^{\circ}$ & $63-64^{\circ}$ & $70-71^{\circ}$ \\
\hline オキシ酸(還元に依る) & $68-69^{\circ}$ & & $51-52^{\circ}$ & \\
\hline
\end{tabular}

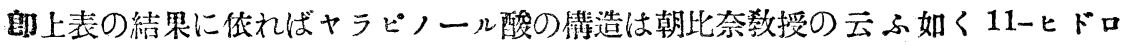
寺シへキサデカン酸なる事友證し得たるもコンヴォルブリノール酸は11ーヒドロキ シヘンタデカン酸と一致せ市。目下此方面の研究進行中なり・上記兩オキン酸の 合成に於て用ふる原料 10ーアルデヒドデカン酸エステルは充分炭酸ソーダ溶液を 以て洗涤して混在せるエステル酸を除き窒素氣流中にて減壓蒸溜を行ひ直ちに之 をアルキルマグネシウムブロミドと反應せしむ可し.份所求オキシ酸エステルを 得乃迄全部窒素氣流中にて操作する時はヒドロキシ酸エステルを容易に純粹狀態 に得べし.

(䄍澤)

メチルアルコホルとアンモニアよりメチラミンの製法Ｔ. L. Davis 
\& R. C. Elderfield: J. Am. Chem. Soc, 50, 1786-89 (1928) Sabatier \& Mailhe 兩 氏等[Compt. rend. 181,893 (1909)]は踆化トリウム上に350-70”にてアンモ二 アと種々なるアルコホルとの蒸氣を通じ第一級アミンの生成を認めたり. 兩氏等

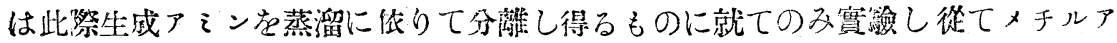
ルコホルに就ては實驗せざりき．面して著者等はメチルアルコホルとアンモニア の混合物を種々なる條件の元に酸化トリウム上に通じモノメチラそンの生成を汧 究し溫度 $325-330^{\circ}$, 混合割合メチルアルコホル 1 モルに對しアンモニア 0.8-0.83

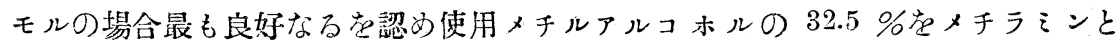
なすを得たり・溫度を $380^{\circ}$ 以上となす時は觸媒は炭素性物質を以て掩はれアル コホルは一酸化炭素, 水素, メン及フォルムアルデヒド等に分解さる・アるンは之 を監酸にて捕へ監化アンモンと分つ.

(管澤)

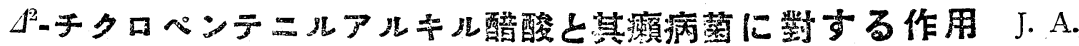

Arvin \& R. Adams: J. Am. Chem. Soc. 5特, 1790-94 (1928) シャウルムウグラ酸 及ヒドノカルプス酸は何れもチクロペンテニル團然有吉. 而してチクロへキシル エチルアルキル醋酸はチクロヘキシルアルキル醋酸よりも其癭病菌に對する作用

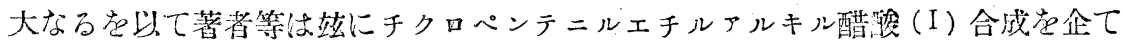

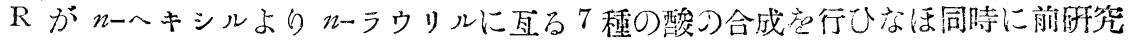
の䋠潰として R がデチル,ウンデチル及びラウリルなる場合つチクロペンテニル アルキル醋陻 (II) の合成をも行ひたり.
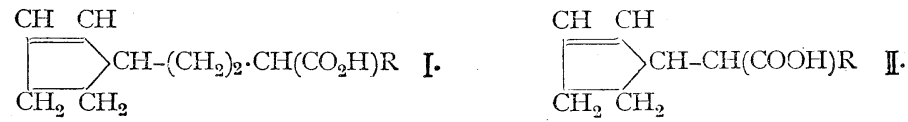

(I) の合成に於ては先づ原料としてチクロペンテニルクロリドを取りそたナト リウムマロン酸エステルと縮合せしめ成績物を䶨化し一炭酸基な脫し對應する醋

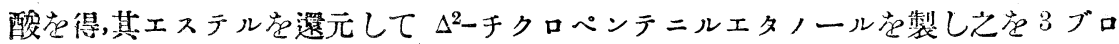
一ム繗にて處理して $\Delta^{2}$-チクロベンテニッェチルブロそドを得. 之より更にマロ ン酸エステル及アルキルハロイドを以てチクロペンテニルェチルアルキルマロン

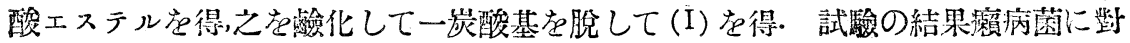
し最も有效なるは炭素數 16 より 18 に到るものにして從來砰筑せし他到化合賗 に於けると同裳なるを認め得. 其强さも他列化合體の同分子量のものと殆ど同渿 なり・而してチクロペンテニル列化合體のものとチクロへキシル列化合體つもの とを此較するに二重結合の存否が生理作用に大なる影響なき事は注目に値す。著

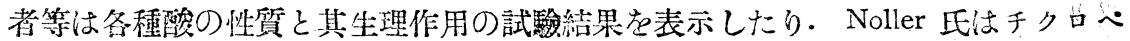
ンテニルェチルマグネシウムブロ ドとアツェライン酸生アルデヒドメチルエネ テルより下式の如く 8 ーヒドロキシーdlーヒドノカルプス酸を製したり。之を還元し 
てヒドノカルプス酸に到達せんとせしが Perkins 氏が他法に依りシャウルムウグラ 酸の合成に成功したるを以て之を中止したり。

$\mathrm{C}_{5} \mathrm{H}_{7} \cdot \mathrm{CH}_{2} \cdot \mathrm{CH}_{2} \cdot \mathrm{Mg} \cdot \mathrm{Br}+\mathrm{OHC} \cdot\left(\mathrm{CH}_{2}\right)_{7} \cdot \mathrm{COOCH}_{3} \longrightarrow \mathrm{C}_{5} \mathrm{H}_{7} \cdot\left(\mathrm{CH}_{2}\right)_{2} \cdot \mathrm{CHOH} \cdot\left(\mathrm{CH}_{2}\right)_{7} \cdot \mathrm{COOCH}_{3}$

ロ-テトラヒドロフルフリルアルコネルのエステル J. E. Zanetti : J. Am. Chem. Soc. 1821-2(1928) a-テトラヒドロフルフリルアルコホルはフルフラ 一ルの接觸還元に依りて容易に得らる・著者は $a$ らルフリルアルコホルのエス テルとの比較の目的を以て今テトラヒド化物のエステルを製したり・テトラヒド ロフルフリルアルコホルはフルフリルアルコホルに比し極めて安定にして賥酸に

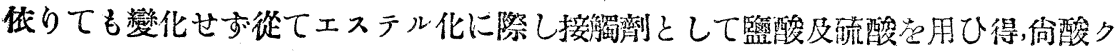
ロリド及び酸無水物に依りてもエステル化さる，得量は焦情粘㳸酸の㻛合の50\% を除き一般に $80 \%$ 上なり・著者の製したるものは下記の如し. 此等の中醋酒参 エステルのみは水と任意の割合に混するも他は然らす。一般に㞣定なり・（管濢） K. P.

\begin{tabular}{|c|c|}
\hline 醋 酸 エ ステル & $194-5^{\prime}$ \\
\hline プロピオン酸エステル & $204-207^{\circ}\left(85-87^{\circ}, 3 \mathrm{~mm}\right)$ \\
\hline 酪 酸 エ ス テ ル & $225-227^{\circ}\left(102-104^{\circ}, 4 \mathrm{~mm}\right)$ \\
\hline ワレリアン酸エステル & $238-240^{\circ}\left(97-99^{\circ}, 2 \mathrm{~mm}\right)$ \\
\hline 酸 エス テ ル & $300-302^{\circ}\left(138-140^{\circ}, 2 \mathrm{~mm}\right)$ \\
\hline 粘液酸エステル & $136-138^{\circ}(3 \mathrm{~mm})$ \\
\hline
\end{tabular}

デピペリデルに就て $\quad$ C. R. Smith : J. Am. Chem. Soc. 50, 1936-38 (1928) 6 種のヂピリヂルに對し6 種のヂピペリヂル存在すべきなり・然るにヂピリヂル

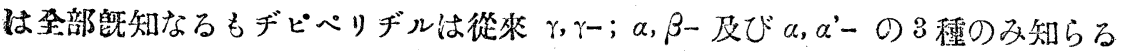
之等は何れも對應するヂピリヂルをナトリウムと酒精或はアミルアルコホルに拣

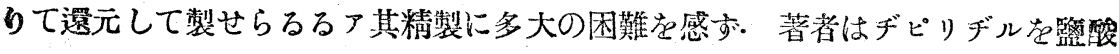
及性水溶腹或は酒精溶液に於て酸化白金一白金黑を用ひ常壓或は加壓の元に接觸

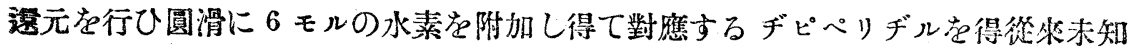
の $\beta, \gamma$ 一及 $\beta, \beta$ ーヂピペリヂルを得たり．唯 $\alpha, \gamma$ のは純粹狀態に得られ亦。ア ルカリ性或は酸を加へざる液中にては僈元進行せす。. 還元監基はヂヒドロクロリ

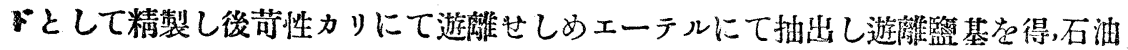
エーテルとエーテル或はエーテルより再結せしむ。融翟 $\beta, \beta$ は $105^{\circ}, \beta, \gamma$ は $159^{\circ}$ なり.

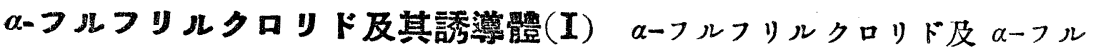
フリルエーテルの製造 W. R. Kirner：J. Am. Chem. Soc. 50, 1955-61 (1928) ローフルフリルクロリドは未だ純粹狀態に得られたるを聞かす。最近 Zanetti 氏 U. Am. 49, 1061；1065 (1927) は $\alpha$ ルフフリルプロiド及ヨーヂドをエーテル 
溶液として製しえより直ちに種々なる

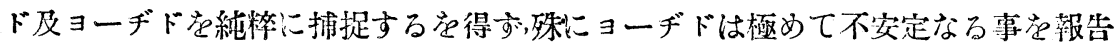

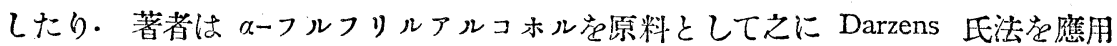
しピリヂンの存在に於てェーテル溶液中チオニルクロリドを作用せしめて フリルクロリド苍得たり. 得量原料アルコホルに對し $63 \%$, 沸點 $27 \mathrm{~mm} に$ 49.6-50’ の無色液體なり、本品は乾燥せるものは充分安定にして分析, 屈析率の 测定及比重の测定等をも行ひ得. 放置する時は渐次黃色となり，次に綠色，終に黑

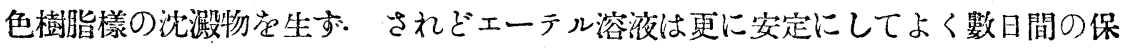
存に想ふ・斯くして得たるクロリドを原料として Zanetti 氏法に從ひ數锤のエー テルを製したり。Zanetti 氏は

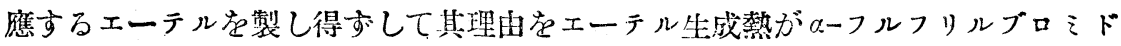
を分解するものとなしたれぞも著者は上に得たるクロリドを原料として $88 \%$ \%の

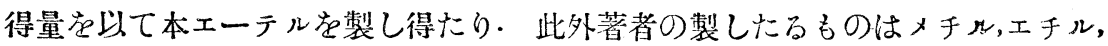

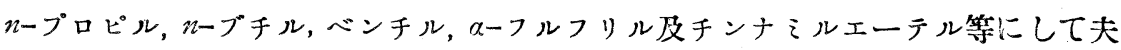
等の沸默得量及諸他の物理的性質を表示したり．你目下クロリドを原料として種 々なるアミン,アセト醋酸エステル,マロン酸エステルの製造及クロリドにグリニ ヤール反應觉應用中哀り。

(菅澤)

ヘプタンデカルボン酸-1,5の合成 A. S. Carter: J. Am. Chem. Soc. 50, 1967-70 (1928) Perkin 氏は上記ヂカルボン酸管合成せんとしてトリメチレンブ

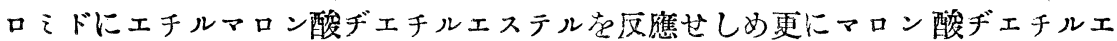
ステルを縮合せしめて成績物を鹼化しへプタンテトラカルボン酸-1,1,5,5 芷得, 之 より炭酸基在脫してへブタンヂカルボン酸-1,5に到達したりしが不純物として， ナンヂカルボン酸-3.7 を夾雜せる䉆所期の酸学絬晶性に得られざりき・依てノナ ンヂカルボン酸-3,7 の生成を避くろ䉆トリメチレンクロロブロ々ドを用ひ或はト リメチンブロそド中へエチルマロン酸ヂェチルエステルを加へたるも所期の目的 を達し得ざりき. 依て著者はトリメチレンブロミドより先づフェノキシブロピル ブロえドを製し之にマロン酸ヂェチルェステル学作用せしめてフェノキシマロン

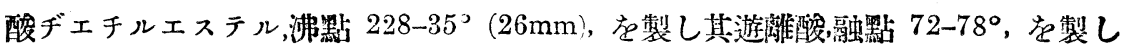

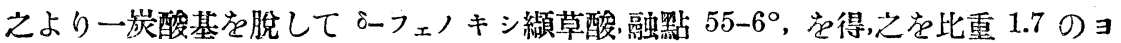

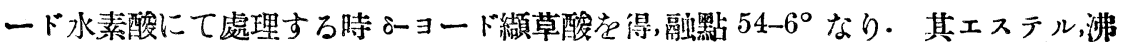
點 108-118 (20mm) をエチルマロン酸ヂェチルェステルと作用せしめへプタント リカルボン酸トリエチルエステルー1,5,5 沸點 $195-200^{\circ}(20 \mathrm{~mm})$ を得,之を簽化して

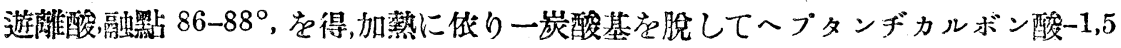

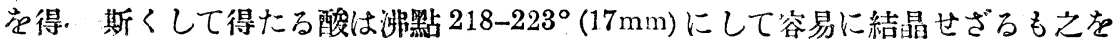

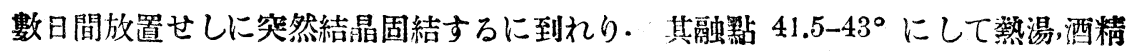

